\title{
PEMBELAJARAN FISIKA MODEL DISKUSI DITINJAU DARI KECERDASAN INTRAPERSONAL SISWA
}

\author{
Utama Alan Deta, Nadi Suprapto
}

\author{
Jurusan Fisika \\ Fakultas Matematika dan Ilmu Pengetahuan Alam \\ Universitas Negeri Surabaya
}

\begin{abstract}
Abstrak
Model pembelajaran diskusi menitikberatkan pada keaktifan siswa. Dalam model pembelajaran diskusi, diperlukan kemampuan siswa dalam menyampaikan pendapat dan menghargai pendapat orang lain. Dengan demikian, secara teori, dalam pelaksanaan pembelajaran dengan model diskusi memerlukan kecerdasan interpersonal yang tinggi. Adapun tujuan dari penelitian ini adalah untuk mengetahui perbedaan hasil belajar model diskusi dengan pembelajaran biasa; kecerdasan interpersonal siswa tinggi dan rendah; serta interaksi antara keduanya. Penelitian ini menggunakan control group post-test,yakni menggunakan satu kelas eksperimen dan kelas kontrol kemudian diuji hasil belajar siswa dengan soal formatif. Berdasarkan hasil penelitian, diperoleh bahwa terdapat perbedaan hasil belajar antara siswa yang diberi pembelajaran fisika model diskusi dengan pembelajaran biasa; tidak terdapat perbedaan hasil belajar antara siswa dengan kecerdasan intrapersonal tinggi dan rendah; dan terdapat interaksi antara model pembelajaran diskusi dengan kecerdasan interpersonal siswa terhadap hasil belajar.
\end{abstract}

Kata Kunci: Model diskusi, kecerdasan interpersonal, dan hasil belajar. 


\section{Pendahuluan}

Terdapat berbagai macam model pembelajaran untuk menyampaikan materi fisika secara menarik. Namun, sering kali penerapan model pembelajaran dinilai kurang tepat dengan kharakteristik materi maupun kharakteristik siswa sehingga penerapan model-model pembelajaran tersebut justru menjadi bumerang bagi guru. Terkadang, guru yang menerapkan model-model pembelajaran inovatif justru menemui kesulitan dalam membimbing siswa untuk memahami materi pelajaran sehingga berdampak pada pemahaman materi pembelajaran siswa yang kurang baik.

Salah satu model pembelajaran yang memerlukan kharakteristik siswa tertentu adalah model diskusi. Model diskusi merupakan salah satu model pembelajaran yang menitikberatkan pada keaktifan siswa dalam berdiskusi. Dengan demikian, penerapan model diskusi memerlukan keahlian siswa dalam berdiskusi. Namun, seringkali penerapan model ini digunakan secara asal-asalan, sehingga siswa justru akan mengalami kesulitan dalam memahami materi yang diajarkan.

Dalam model pembelajaran diskusi, diperlukan kemampuan siswa dalam menyampaikan pendapat dan menghargai pendapat orang lain. Menurut Gardner [1], kemampuan siswa dalam hal berinteraksi dengan orang lain dikategorikan dengan kecerdasan intrapersonal. Dengan demikian, orang yang memiliki kecerdasan intrapersonal tinggi memiliki kemampuan untuk berkomunikasi dan berdiskusi dengan baik. Diharapkan, siswa yang memiliki kecerdasan intrapersonal tinggi akan mudah memahami materi dengan berdiskusi, sehingga cocok diajar dengan model pembelajaran diskusi.

Berdasarkan uraian di atas, dapat dirumuskan permasalahan penelitian sebagai berikut:

a. Apakah ada perbedaan hasil belajar antara siswa yang diberi pembelajaran
Fisika model diskusi dengan pembelajaran biasa?

b. Apakah ada perbedaan hasil belajar antara siswa dengan kecerdasan intrapersonal tinggi dan rendah?

c. Apakah ada interaksi antara model pembelajaran diskusi dengan kecerdasan interpersonal siswa terhadap hasil belajar?

\section{Kajian Teori}

\subsection{Model Diskusi}

Diskusi bukan merupakan model pengajaran sebenarnya, tetapi merupakan prosedur atau strategi mengajar. Diskusi merupakan situasi dimana siswa-siswa dihadapkan kepada suatu masalah yang bisa berupa pernyataan atau pertanyaan yang bersifat problematis untuk dibahas dan dipecahkan bersama sehingga antara guru dengan siswa atau siswa dengan siswa yang lain bertukar gagasan dan pendapat satu sama lain. Diskusi dilakukan oleh guru untuk mencapai sedikitnya tiga tujuan pembelajaran khusus yang penting, antara lain :

a. Diskusi meningkatkan cara berfikir siswa dan membantu mereka membangun sendiri pemahaman isi pelajaran

b. Diskusi menumbuhkan keterlibatan dan keikutsertaan siswa

c. Diskusi dapat membantu siswa mempelajari keterampilan komunikasi dan proses berfikir yang penting.

Penyelenggaraan diskusi memiliki beberapa tahapan. Menurut Tjokrodihardjo [2] tahapan-tahapan dalam model pembelajaran diskusi sebagai berikut :

a. Tahap 1 Menyampaikan tujuan dan mengatur setting. Guru menyampaikan tujuan diskusi, mengatur setting tempat duduk, dan menyiapkan siswa untuk berpartisipasi.

b. Tahap 2 Mengarahkan diskusi. Guru mengarahkan fokus diskusi dengan menguraikan aturan-aturan dasar, mengajukan pertanyaan-pertanyaan awal, menyajikan situasi yang tidak 
dapat segera dijelaskan, atau menyampaikan isu diskusi.

c. Tahap 3 Menyelenggarakan diskusi. Guru memonitor antar aksi para siswa, mengajukan pertanyaan, mendengarkan gagasan, melaksanakan aturanaturan dasar, membuat catatan diskusi serta menyampaikan gagasan sendiri.

d. Tahap 4 Mengakhiri diskusi. Guru menutup diskusi dengan merangkum atau mengungkapkan makna diskusi yang telah diselenggarakan kepada siswa.

e. Tahap 5 Melakukan tanya jawab singkat tentang proses diskusi. Guru meminta siswa untuk memeriksa proses diskusi dan berfikir mereka.

\subsection{Kecerdasan Interpersonal}

Inteligensi intrapersonal adalah kemampuan yang berkaitan dengan pengetahuan akan diri sendiri dan kemampuan untuk bertindak secara adaptatif berdasarkan pengenalan diri itu [1]. Kemampuan berefleksi dan keseimbangan diri termasuk dalam inteligensi ini. Orang-orang dengan kecerdasan intrapersonal yang berkembang dengan baik memiliki ciri-ciri sebagai berikut [3]:

a. Mampu menyadari dan mengerti arti emosi diri sendiri dan emosi orang lain.

b. Mampu mengungkapkan dan menyalurkan perasaan dan pikiran.

c. Mengembangkan konsep diri yang baik dan benar.

d. Termotivasi untuk menentukan dan mengejar suatu tujuan hidup.

e. Menetapkan dan hidup dengan sistem nilai yang sesuai dengan etika.

f. Mampu bekerja secara mandiri.

g. Sangat tertarik dengan pertanyaan arti hidup, tujuan hidup, dan relevansinya dengan keadaan saat ini.

h. Mampu mengembangkan kemampuan belajar yang berkelanjutan dan meningkatkan diri.

i. Mampu menyelami dan mengerti kerumitan suatu pribadi dan kondisi manusia pada umumnya.
Untuk mengembangkan kecerdasan intrapersonal, dapat dilakukan dengan beberapa cara, yakni [4]:

a. Sediakan waktu untuk merefleksikan diri.

b. Membaca buku motivasi dan pengembangan diri.

c. Mengikuti pelatihan, seminar dan workshop motivasi dan pengembangan diri.

d. Melakukan meditasi dan penemuan diri setiap hari.

\subsection{Penelitian yang Relevan}

Utama Alan Deta, dkk [5] dengan judul penelitian "Penerapan Teori Multiple Intelligences dalam Pembelajaran Fisika SMP Kelas VIII Semester 2 Bab Bunyi" menyimpulkan bahwa pembelajaran dengan menggunakan pendekatan teori Multiple Intelligences dapat meningkatkan hasil belajar serta respon siswa terhadap pembelajaran. Dengan demikian, kharakteristik kecerdasan siswa sangat penting dalam menujang proses belajar mengajar. Siswa yang diajar dengan model pembelajaran yang sesuai kharakteristik siswa tentu akan memberikan hasil yang lebih baik dibandingkan dengan pembelajaran dengan model tertentu tanpa memperhatikan kharakteristik siswa.

Dwi Fatimah C.N. [6] dengan judul penelitian "Pengaruh Penerapan Tutor Sebaya (Peer Tutor) dalam Model Pembelajaran Diskusi terhadap Hasil Belajar Siswa Pada Materi Alat Optik Kelas VIII SMP Negeri 1 Karangrejo Magetan" menyimpulkan bahwa penerapan tutor sebaya (peer tutor) dalam model pembelajaran diskusi tidak hanya meningkatkan kemampuan kognitif siswa saja tetapi juga meningkatkan kemampuan afektif dan psikomotor siswa. Adapun metode tutor sebaya sangat menuntut peran aktif dan kemampuan siswa dalam mengkomunikasikan materi. Dengan demikian, perlu tinjauan khusus mengenai sasaran penerapan model pembelajaran diskusi agar lebih efektif dalam meningkatkan kemampuan siswa. 


\subsection{Hipotesis}

Berdasarkan dasar teori dan penelitian yang relevan, maka diduga:

a. Terdapat perbedaan hasil belajar antara siswa yang diberi pembelajaran Fisika model Diskusi dengan pembelajaran biasa.

b. Terdapat perbedaan hasil belajar antara siswa dengan kecerdasan intrapersonal tinggi dan rendah.

c. Terdapat interaksi antara model pembelajaran diskusi dengan kecerdasan interpersonal siswa terhadap hasil belajar.

\section{Metode Penelitian}

\subsection{Jenis Penelitian}

Jenis penelitian yang digunakan adalah penelitian true experimental design. Adapun bentuk true experimental design yang dipilih dalam penelitian ini adalah control group post-test [7]. Penelitian ini akan dilaksanakan di SMP Negeri 1 Dawar Blandong Mojokerto yang beralamat di Desa Dawar Blandong Kabupaten Mojokerto pada tanggal 11 Oktober 2010 hingga tanggal 4 November 2010.

\subsection{Populasi dan Sampel Penelitian}

Adapun populasi dalam penelitian ini adalah siswa kelas VIII RSBI di SMPN 1 Dawar Blandong semester gasal tahun ajaran 2010/2011 yang berjumlah 2 (dua) kelas. Penelitian ini menggunakan control group post-test, sampel dipilih scara random sampling.

\subsection{Variabel-Variabel Penelitian}

\subsubsection{Variabel Bebas}

Variabel bebas dalam penelitian ini adalah penerapan model diskusi dan kecerdasan interpersonal. Kecerdasan interpersonal siswa diukur dengan tes Multiple Intelligences Scale (MIS) digolongkan menjadi tinggi dan rendah.

3.3.2. Variabel Terikat

Variabel terikat dalam penelitian ini adalah hasil belajar belajar siswa. Hasil belajar siswa dalam penelitian ini mencakup ranah kognitif saja. Hasil belajar kognitif siswa diukur dengan menggunakan post-test.

\subsubsection{Variabel Respon}

Variabel kontrol dalam penelitian ini adalah materi pembelajaran, guru atau pendidik, dan alokasi waktu pembelajaran. Adapun materi pembelajaran yang digunakan dalam penelitian ini adalah materi pesawat sederhana. Adapun guru yang melakukan pembelajaran adalah peneliti dengan dibantu oleh seorang observer dan seorang guru bidang studi fisika. Alokasi waktu pembelajaran adalah 2 x 3 x 40 menit, adapun waktu untuk posttest adalah 60 menit.

\subsection{Instrumen Penelitian}

Instrumen penelitian merupakan alat yang digunakan untuk mengumpulkan data penelitian. Dalam hal ini instrumen penelitian yang digunakan meliputi :

a. Lembar Tes MIS (Multiple Intelligences Scale)

Tes MIS (Multiple Intelligences Scale) adalah pengukuran terhadap sasaran didik untuk mengetahui kecerdasan dominan pada masing - masing siswa. Tes MIS yang digunakan dalam penelitian ini adalah hasil adaptasi tes MIS dari www.bussinesball.com yang telah disesuaikan dengan siswa. Dengan demikian, dapat dilakukan pembelajaran yang sesuai dengan kecerdasan yang dominan pada siswa.

b. Lembar Soal Post-test

Tes yang digunakan dalam penelitian ini adalah berupa tes yang dilaksanakan diakhir pembelajaran. Tes hasil belajar siswa yang digunakan untuk mengukur kemampuan siswa sesudah pelaksanaan pembelajaran pada materi pokok Pesawat Sederhana.

\subsection{Teknik Analisis Data}

Untuk menguji hipotesis penelitian dilakukan uji ANOVA menggunakan SPSS versi 20. Adapun prasyarat dari ANOVA adalah sampel berasal dari populasi normal dan homogen. Dengan demikian, sebelum melakukan uji ANOVA, dilakukan uji prasyarat analisis berupa uji normalitas dan homogenitas. Berikut ini adalah hipotesis nol yang akan diuji dalam penelitian ini. 
$\mathrm{H}_{01}=$ tidak terdapat perbedaan hasil belajar antara siswa yang diberi pembelajaran Fisika model diskusi dengan pembelajaran biasa.

$\mathrm{H}_{02}=$ tidak terdapat perbedaan hasil belajar antara siswa dengan kecerdasan intrapersonal tinggi dan rendah.

$\mathrm{H}_{03}=$ tidak terdapat interaksi antara model pembelajaran diskusi dengan kecerdasan interpersonal siswa terhadap hasil belajar.

Adapun kriteria dari uji ANOVA adalah tolak H0 jika signifikansi kurang dari alpha 0.05 .

\section{Hasil dan Pembahasan \\ 4.1 Data Hasil Penelitian}

Berikut ini adalah data hasil penelitian.

Tabel 1. Data Hasil Penelitian

\begin{tabular}{|c|c|c|c|c|c|c|c|c|c|}
\hline \multirow[b]{2}{*}{$\begin{array}{l}\text { No } \\
\text { Siswa }\end{array}$} & \multicolumn{2}{|c|}{ Diskusi } & \multicolumn{2}{|c|}{ Kontrol } & \multirow[b]{2}{*}{$\begin{array}{l}\text { No } \\
\text { Siswa }\end{array}$} & \multicolumn{2}{|c|}{ Diskusi } & \multicolumn{2}{|c|}{ Kontrol } \\
\hline & $\begin{array}{l}\text { Hasil } \\
\text { Belajar }\end{array}$ & $\begin{array}{l}\text { Kecer-dasan } \\
\text { Inter- } \\
\text { personal }\end{array}$ & $\begin{array}{c}\text { Hasil } \\
\text { Belajar }\end{array}$ & $\begin{array}{l}\text { Kecer-dasan } \\
\text { Inter- } \\
\text { personal }\end{array}$ & & $\begin{array}{c}\text { Hasil } \\
\text { Belajar }\end{array}$ & $\begin{array}{c}\text { Kecer-dasan } \\
\text { Inter- } \\
\text { personal }\end{array}$ & $\begin{array}{c}\text { Hasil } \\
\text { Belajar }\end{array}$ & $\begin{array}{c}\text { Kecer-dasan } \\
\text { Inter- } \\
\text { personal }\end{array}$ \\
\hline 1 & 65 & 5 & 70 & 10 & 17 & 85 & 9 & 80 & 12 \\
\hline 2 & 80 & 10 & 85 & 5 & 18 & 90 & 8 & 70 & 9 \\
\hline 3 & 90 & 6 & 80 & 5 & 19 & 80 & 18 & 80 & 16 \\
\hline 4 & 75 & 5 & 85 & 16 & 20 & 90 & 12 & 75 & 8 \\
\hline 5 & 85 & 9 & 60 & 10 & 21 & 70 & 9 & 70 & 9 \\
\hline 6 & 80 & 5 & 90 & 13 & 22 & 90 & 8 & 70 & 17 \\
\hline 7 & 80 & 9 & 80 & 18 & 23 & 95 & 17 & 65 & 14 \\
\hline 8 & 95 & 9 & 70 & 7 & 24 & 75 & 16 & 65 & 16 \\
\hline 9 & 70 & 8 & 80 & 6 & 25 & 90 & 9 & 75 & 10 \\
\hline 10 & 80 & 14 & 65 & 6 & 26 & 85 & 7 & 70 & 9 \\
\hline 11 & 90 & 12 & 80 & 11 & 27 & 80 & 9 & 75 & 7 \\
\hline 12 & 80 & 9 & 70 & 10 & 28 & 95 & 10 & 70 & 9 \\
\hline 13 & 95 & 8 & 80 & 9 & 29 & 85 & 8 & 65 & 10 \\
\hline 14 & 85 & 12 & 60 & 11 & 30 & 75 & 9 & 70 & 7 \\
\hline 15 & 75 & 11 & 80 & 16 & 31 & 85 & 12 & & \\
\hline 16 & 100 & 10 & 75 & 16 & 32 & 80 & 9 & & \\
\hline
\end{tabular}

\subsection{Uji Prasyarat Hipotesis}

Uji Normalitas menggunakan uji Kolmogorov-Smirnov dengan bantuan program SPSS versi 20. Adapun kriteria dari uji Normalitas adalah data terdistribusi normal jika signifikansi lebih besar dari alpha 0.05. Berikut ini adalah hasil uji normalitas dari data hasil belajar. 
Tabel 2. Hasil Uji Normalitas

\begin{tabular}{|c|c|c|c|c|}
\hline $\begin{array}{l}\text { Hipotesi } \\
\mathrm{s}\end{array}$ & $\begin{array}{l}\mathrm{N} \\
\mathrm{O}\end{array}$ & $\begin{array}{l}\text { Kelompok } \\
\text { Data }\end{array}$ & Sig & $\begin{array}{l}\text { Kesimpula } \\
\mathrm{n}\end{array}$ \\
\hline \multirow[t]{2}{*}{ H1 } & 1 & $\begin{array}{l}\text { Model } \\
\text { Diskusi }\end{array}$ & $\begin{array}{l}0.14 \\
4\end{array}$ & Normal \\
\hline & 2 & Pemb Biasa & $\begin{array}{l}0.00 \\
9\end{array}$ & $\begin{array}{l}\text { Tidak } \\
\text { Normal }\end{array}$ \\
\hline \multirow[t]{2}{*}{$\mathrm{H} 2$} & 1 & $\begin{array}{l}\text { Kec } \\
\text { Interperson } \\
\text { al Tinggi }\end{array}$ & $\begin{array}{l}0.16 \\
1\end{array}$ & Normal \\
\hline & 2 & $\begin{array}{l}\text { Kec } \\
\text { Interperson } \\
\text { al Rendah }\end{array}$ & $\begin{array}{l}0.03 \\
6\end{array}$ & $\begin{array}{l}\text { Tidak } \\
\text { Normal }\end{array}$ \\
\hline \multirow[t]{4}{*}{ H3 } & 1 & $\begin{array}{l}\text { Model } \\
\text { Diskusi, } \\
\text { Kec } \\
\text { Interperson } \\
\text { al Tinggi } \\
\end{array}$ & $\begin{array}{l}0.20 \\
0\end{array}$ & Normal \\
\hline & 2 & $\begin{array}{l}\text { Model } \\
\text { Diskusi, } \\
\text { Kec } \\
\text { Interperson } \\
\text { al Rendah }\end{array}$ & $\begin{array}{l}0.20 \\
0\end{array}$ & Normal \\
\hline & 3 & $\begin{array}{l}\text { Pemb } \\
\text { Biasa, Kec } \\
\text { Interperson } \\
\text { al Tinggi }\end{array}$ & $\begin{array}{l}0.14 \\
3\end{array}$ & Normal \\
\hline & 4 & $\begin{array}{l}\text { Pemb } \\
\text { Biasa, Kec } \\
\text { Interperson } \\
\text { al Rendah }\end{array}$ & $\begin{array}{l}0.00 \\
5\end{array}$ & $\begin{array}{l}\text { Tidak } \\
\text { Normal }\end{array}$ \\
\hline
\end{tabular}

Karena terdapat data hasil belajar di setiap kelompok hipotesis yang tidak terdistribusi normal, maka dilakukan uji statistik non-parametrik yang setara dengan uji ANOVA yakni uji KruskalWallis One Way ANOVA. Uji Homogenitas tidak perlu dilakukan karena terdapat data tidak terdistribusi normal pada tiap kelompok hipotesis sehingga sudah dapat dipastikan pengujian tidak dapat menggunakan statistika parametrik.

\subsection{Uji Hipotesis}

Uji hipotesis menggunakan uji Kruskal-Wallis One Way ANOVA dengan software SPSS versi 20. Adapun kriteria dari uji ANOVA adalah tolak $\mathrm{H} 0$ jika signifikansi kurang dari alpha 0.05. Berikut ini adalah hasil uji hipotesis nol pertama.

Tabel 3. Hasil Uji Hpotesis Nol Pertama Test Statistics ${ }^{\mathrm{a}, \mathrm{b}}$

\begin{tabular}{|l|r|}
\hline & Hasil_Belajar \\
\hline Chi-Square & 17.424 \\
df & 1 \\
Asymp. Sig. & .000 \\
\hline
\end{tabular}

a. Kruskal Wallis Test

b. Grouping Variable: Model

Berdasarkan hasil uji Kruskal-Wallis terhadap hipotesis nol pertama, diperoleh signifikansi 0.000 lebih kecil dari alpha 0.05. Disimpulkan bahwa terdapat perbedaan hasil belajar antara siswa yang diberi pembelajaran Fisika model diskusi dengan pembelajaran biasa. Adapun ratarata hasil belajar siswa yang diajar dengan model diskusi lebih tinggi dibandingkan dengan pembelajaran biasa. Hal ini menunjukkan bahwa model pembelajaran diskusi lebih baik daripada pembelajaran biasa. Dengan model diskusi, siswa lebih aktif dalam mengeksplorasi dan mengkomunikasikan materi pelajaran sehingga dapat meningkatkan pemahaman siswa terhadap materi yang dibahas.

Berikut ini adalah hasil uji hipotesis nol kedua.

Tabel 4. Hasil Uji Hipotesis Nol Kedua Test Statistics ${ }^{\mathrm{a}, \mathrm{b}}$

\begin{tabular}{|l|r|}
\hline & \multicolumn{2}{|c|}{ Hasil_Belajar } \\
\hline Chi-Square & .013 \\
df & 1 \\
Asymp. Sig. & .909 \\
\hline
\end{tabular}

a. Kruskal Wallis Test

b. Grouping Variable: Kecerdasan_Intrapersonal

Berdasarkan hasil uji Kruskal-Wallis terhadap hipotesis nol kedua, diperoleh signifikansi 0.909 lebih besar dari alpha 0.05. Disimpulkan bahwa tidak terdapat perbedaan hasil belajar antara siswa dengan kecerdasan interpersonal tinggi dan rendah. Kecerdasan interpersonal terbukti tidak berpengah terhadap pemahaman siswa mengenai materi pelajaran, khusunya pada mata pelajaran fisika. Hal ini dikarenakan dalam materi yang dibahas (pesawat sederhana), cenderung memerlukan kemampuan matematis dan visual dalam menganalisis letak titik beban, kuasa, dan tumpu dari tuas, serta menghitung keuntungan mekanis; sehingga tidak memerlukan kecerdasan interpersonal yang tinggi dalam mempelajari materi pesawat sederhana.

Berikut ini adalah hasil uji hipotesis nol ketiga. 
Tabel 5. Hasil Uji Hipotesis Nol Ketiga Test Statistics ${ }^{\mathrm{a}, \mathrm{b}}$

\begin{tabular}{|l|r|}
\hline & \multicolumn{1}{|c|}{ Hasil_Belajar } \\
\hline Chi-Square & 18.215 \\
Df & 3 \\
Asymp. Sig. & .000 \\
\hline
\end{tabular}

a. Kruskal Wallis Test

b. Grouping Variable: Hipotesis_3

Berdasarkan hasil uji Kruskal-Wallis terhadap hipotesis nol ketiga, diperoleh signifikansi 0.000 lebih kecil dari alpha 0.05. Disimpulkan bahwa terdapat interaksi antara model pembelajaran diskusi dengan kecerdasan interpersonal siswa terhadap hasil belajar. Dengan demikian, siswa yang memiliki kecerdasan interpersonal tinggi menunjang proses diskusi sehingga kegiatan diskusi kelas berlangsung dengan baik. Sebaliknya, siswa yang tidak memiliki kecerdasan interpersonal tinggi akan mengalami kesulitan dalam diskusi.

\section{Kesimpulan dan Saran}

Berdasarkan hasil penelitian, diperoleh kesimpulan sebagai berikut.

a. Terdapat perbedaan hasil belajar antara siswa yang diberi pembelajaran Fisika model diskusi dengan pembelajaran biasa.

b. Tidak terdapat perbedaan hasil belajar antara siswa dengan kecerdasan intrapersonal tinggi dan rendah.

c. Terdapat interaksi antara model pembelajaran diskusi dengan kecerdasan interpersonal siswa terhadap hasil belajar.

Adapun saran dari penulis untuk penelitian selanjutnya adalah:

a. Dalam menerapkan model pembelajaran yang inovatif, perlu diperhatikan kharakteristik siswa sehingga dapat menunjang pelaksanaan model pembelajaran tersebut.

b. Model pembelajaran diskusi sebaiknya diterapkan pada siswa yang memiliki kecerdasan interpersonal yang tinggi.

\section{Daftar Pustaka}

[1] Suparno, Paul (2008), Teori Inteligensi Ganda dan Aplikasinya di Sekolah, Yogyakarta : Kanisius, p.41.

[2] Tjokrodihardjo, Soegijo (2000), Diskusi Kelas, Surabaya : UNESA, p.5.

[3] Gunawan, Adi W. (2007), Born to be a Genius, Jakarta : PT Gramedia Pustaka Utama, p.114 - 115.

[4] Prasetyo, Reza dan Yeni Andriani (2009), Multiply Your Multiple Intelligences, Yogyakarta : Andi, p.51-55.

[5] Deta, Utama Alan, dkk (2009), Penerapan Teori "Multiple Intelligences" dalam Pembelajaran Fisika SMP Kelas VIII Semester 2 Bab Bunyi, diseminarkan dalam the International Seminar and Workshop on Mathematics and Science Teaching Innovation Committee di UNY Yogyakarta tahun 2009, p.3.

[6] Ninggar, Dwi Fatimah C. (2011), Pengaruh Penerapan Tutor Sebaya (Peer Tutor) dalam Model Pembelajaran Diskusi terhadap Hasil Belajar Siswa Pada Materi Alat Optik Kelas VIII SMP Negeri 1 Karangrejo Magetan, Skripsi Tidak Dipublikasikan, Universitas Negeri Surabaya, p.63-64.

[7] Arikunto, Suharsimi (2006), Prosedur Penelitian Suatu Pendekatan Praktik (Edisi Revisi VI), Jakarta : PT Rineka Cipta, p.86. 